\title{
REVERSE LOGISTICS: A REVIEW OF LITERATURE
}

\author{
S. Senthil ${ }^{1}$, R.Sridharan ${ }^{2}$ \\ ${ }^{1}$ Associate Professor, Department of Mechanical Engineering, Kamaraj College of Engineering and Technology, \\ Virudhunagar, Tamilnadu, India \\ ${ }_{2}^{2}$ Professor, Department of Mechanical Engineering, National Institute of Technology Calicut, Calicut, Kerala, India
}

\begin{abstract}
This paper reviews the practice in reverse logistics through published literature. The objective of this study is to encourage and provide researchers with future research directions in reverse logistics. Since supply chains are designed for forward flow, integrating product recovery into the network design poses a major challenge. An important assignment of top management is to analyse the obstacles of reverse logistics which could be vital to the survival of the industry in the future.
\end{abstract}

Keywords: Reverse logistics, Multi-criteria, Decision making, Network design

\section{INTRODUCTION}

Environmental awareness and recycling regulations have been putting pressure on many manufacturers and consumers to dispose used products in an environmentally responsible manner. Reverse logistics (RL) is a part of a broader supply chain management process called returns management. A complete supply chain should include both forward logistics and reverse logistics. Forward logistics operations subsequently increase the reverse logistics activities and thus it plays an important role in the organization success [1]. Researchers have reported several benefits that could be achieved with RL, namely efficient resource utilization and environmental protection $[2,3]$.

Due to the interdisciplinary and cross functional nature of reverse logistics, it provides a fertile and attractive research area in the field of operations management [4]. Sheriff et al., [5] develop a framework to classify the various issues/parameters affecting strategic level decisions in reverse logistics. Dowlatshahi [6] propose a framework for effective design and implementation of reverse logistics operations. An extensive review of research on reverse logistics is presented [7.8, 9].

\section{DECISION MAKING IN RL}

A conceptual framework for managing retail reverse logistics operation is presented in [10].In the case study conducted by [11], three companies were visited and identified reverse logistics process flow and the strategic issues a firm may use for competitive advantage. A model for green supply chain management with incomplete information is developed[12] .Reverse logistics is suggested as an area for future research and the advantages are discussed[13]. A dynamic model is constructed and validated using the data collected from the computer company [14]. A distribution system which uses a combination of manufacturing and remanufacturing is proposed and the models are compared with respect to the various prices [15].
A pricing decisions model for a fuzzy closed-loop supply chain with retail competition in the marketplace was considered in [16]. Delphi method is applied to differentiate the criteria for evaluating traditional suppliers and green suppliers [17, 18]. Dat et al., [19] presents a mathematical programming model which minimizes the total processing cost of multiple types of waste electrical \& electronic products. Pochampully and Gupta [20] use fuzzy AHP in a reverse supply chain to select the most economical product to be reprocessed and the potential recovery facilities.

Büyüközkan and Çifçi[21] propose a hybrid fuzzy multicriteria decision making model for evaluating green suppliers. Ravi, et al., [4] propose a combination of balanced scorecard and analytic network process to provide a more realistic and accurate representation for conducting reverse logistics operations for end-of-life computers. Ferna'ndez and Kek"ale[3] propose a conceptual model using Delphi and AHP as an aid to determine which variables caused reverse logistics success. However AHP \&ANP have weakness in the number of pairwise comparisons required could become cumbersome. Biehl et al., [22] simulate a carpet RL supply chain which uses a designed experiment to analyze the impact of the system design factors on the operational performance of the RL system. Pochampally and Gupta [23] propose a TOPSIS-based methodology to rate candidate companies that collect and sell used products.

Rahman and Subramaninan[24] use the cognition mapping process to identify the critical factors in designing and implementing end-of-life (EOL) computer recycling operations in reverse logistics. Vachon [25] analyses the relationship between environmental collaboration and environmental monitoring in a supply chain. Ramirez[26] indicates that managing cost returns influences the organizational performance.

\section{SELECTION OF RL PROVIDER}

Byrne [27] indicates that 86 per cent of RL decision makers believe that outsourcing gave them more control over their 
operations and 55 per cent of RL decision makers believe that outsourcing assisted them to implement changes faster and more effectively. By outsourcing reverse logistics activities, the organizations can concentrate on their core business operation, but customer satisfaction and delivery performance may be improved .Kannan \& Murugesan [28] present fuzzy extent analysis for selecting third-party reverse logistics provider for the battery industry. Azadi \&Saen [29] propose a chance-constrained data envelopment analysis for selection in the presence of dual role factors. Zhihong and Qiang [30] present a grey comprehensive model based on AHP and grey relational analysis for the selection of RL providers. Meade and Sarkis [31] propose analytical network process model for the reverse logistics provider selection. However the number of pairwise comparison required could become cumbersome. Efendigil et al., [32] propose artificial neural network and fuzzy analytical hierarchy process to select the third party logistics provider in the presence of vagueness.

Amin and Zhang [33] present an integrated model for supplier selection, order allocation, and closed loop network configuration. Xiangru [34] evaluate third party reverse logistics provider(3PRLP) with fuzzy comprehensive evaluation method. Govindan et al.[1] develop a model using interpretive structural modeling(ISM) to analyze the relationship among the attributes of 3PRLP. However the model has not been statistically validated. Kannan et al., [35] use ISM and fuzzy TOPSIS for the selection of reverse logistics provider. Sasikumar and Haq [36] propose the fuzzy VIKOR method and integrated the distribution network to 3PRLP selection. Saen [37] use data envelopment analysis in the presence of multiple dual roles for selecting third party reverse logistics provider.

\section{REVERSE LOGISTICS NETWORK DESIGN}

The design of reverse logistics network is a difficult problem because of its economic aspects and its effects on other aspects of human life, namely, the environment and sustainability of natural resources [38,39]. Logistics network design problems that take into account the facility locations and the shipment of the product flows have been considered in the past.

Pishvaee et al.,[40] develop a new hybrid credibility based fuzzy mathematical programming for green logistics network design. Lee et al.,[41]use genetic algorithm for solving a three stage reverse logistics network model for minimizing the total cost. A mathematical model for the design of reverse logistics network design is proposed $[42,43,44]$ considering the location and allocation of facilities. An integrated forward logistics multi echelon distribution inventory supply chain model and closed loop multi echelon distribution for the built to order environment is designed using genetic algorithm and particle swarm optimization[45].

Figueiredo and Mayerle[46]present a conceptual framework, an analytical model, and a three-stage algorithmic solution for solving designing minimum-cost recycling networks with required throughput. The proposed network structure consists of three echelons in the forward direction and two echelons, in the reverse direction. Vahdani et al. [47] propose a novel model for designing a reliable network of facilities in closed-loop supply chain under uncertainty. Many researchers have investigated the various issues in a deterministic environment. Kroon and Vrijens [48] have considered the design of a logistics system for used plastic containers. They propose a mixed integer linear programming model to determine the number of containers required to run a five echelon system under consideration with an appropriate service, distribution and collection fee per shipment for empty containers and location of depots for empty containers. Piplani and Saraswat [49] propose a mixed-integer linear programming for optimizing the reverse logistics network to minimise the total cost. Mishra et al.., [50] propose a multi-agent architecture to handle recycling and reverse logistics and to facilitate the efficient logistics of materials between different units.

Multi-objective optimization models have been developed for the design of reverse logistics network [51, 52]. Some researchers have modelled the reverse logistics network design problems under uncertainty. Lieckens and Vandaele[53] propose a planning model with integrated quality routing that explicitly takes into account stochastic delays. Ramezani[54] present a stochastic multi-objective model for forward/reverse logistics under uncertain environment. The objectives considered are maximization of profit, customer responsiveness, quality. The set of Paretooptimal solutions is obtained and the financial risk is also computed.The summary of articles in reverse logistics is shown in Table 1.

Table -1: Summary of articles in reverse logistics

\begin{tabular}{|c|c|c|c|c|}
\hline $\begin{array}{l}\text { Sl. } \\
\text { No }\end{array}$ & Reference & Topic & $\begin{array}{l}\text { Material } \\
\text { in }\end{array}$ & $\begin{array}{l}\text { Material } \\
\text { out }\end{array}$ \\
\hline 1 & [55] & $\begin{array}{l}\text { Reverse } \\
\text { logistics } \\
\text { networks }\end{array}$ & $\begin{array}{l}\text { Recyclabl } \\
\text { es in } \\
\text { general }\end{array}$ & Materials \\
\hline 2 & [56] & $\begin{array}{l}\text { Purchase } \\
\text { of } \\
\text { recycled } \\
\text { materials }\end{array}$ & Paper & Paper \\
\hline 3 & [57] & $\begin{array}{l}\text { Logistic } \\
\text { implicatio } \\
\text { ns of } \\
\text { recycling } \\
\text { programs }\end{array}$ & $\begin{array}{l}\text { Recyclabl } \\
\text {-es in } \\
\text { general }\end{array}$ & Materials \\
\hline 4 & [58] & $\begin{array}{l}\text { Planning } \\
\text { and } \\
\text { control of } \\
\text { recovery } \\
\text { activities }\end{array}$ & $\begin{array}{l}\text { Glass } \\
\text { scrap }\end{array}$ & $\begin{array}{l}\text { Raw } \\
\text { materials }\end{array}$ \\
\hline 5 & [59] & $\begin{array}{l}\text { Reverse } \\
\text { logistics } \\
\text { network }\end{array}$ & $\begin{array}{l}\text { House } \\
\text { hold waste }\end{array}$ & $\begin{array}{l}\text { Substitute } \\
\mathrm{s} \quad \text { for } \\
\text { primary } \\
\text { material }\end{array}$ \\
\hline 6 & [60] & $\begin{array}{l}\text { Incentives } \\
\text { to }\end{array}$ & Batteries & Materials \\
\hline
\end{tabular}




\begin{tabular}{|c|c|c|c|c|}
\hline & & $\begin{array}{l}\text { stimulate } \\
\text { recovery }\end{array}$ & & \\
\hline 7 & [61] & $\begin{array}{l}\text { Reverse } \\
\text { logistics } \\
\text { network }\end{array}$ & $\begin{array}{l}\text { Steel } \\
\text { products }\end{array}$ & $\begin{array}{l}\text { reusable } \\
\text { products }\end{array}$ \\
\hline 8 & [62] & $\begin{array}{l}\text { Incentives } \\
\text { to } \\
\text { stimulate } \\
\text { recovery }\end{array}$ & Batteries & $\begin{array}{l}\text { Raw } \\
\text { materials } \\
\text { Batteries }\end{array}$ \\
\hline 9 & [63] & $\begin{array}{l}\text { Reverse } \\
\text { logistics } \\
\text { networks }\end{array}$ & $\begin{array}{l}\text { Constucti- } \\
\text { on waste }\end{array}$ & Sand \\
\hline 10 & [64] & $\begin{array}{l}\text { Informatio } \\
\mathrm{n} \text { and } \\
\text { Communi } \\
\text { cation for } \\
\text { reverse } \\
\text { logistics }\end{array}$ & $\begin{array}{l}\text { End-of- } \\
\text { use } \\
\text { Refrig- } \\
\text { erators }\end{array}$ & $\begin{array}{l}\text { Plastics } \\
\text { Metals }\end{array}$ \\
\hline 11 & {$[65,66]$} & $\begin{array}{l}\text { Reverse } \\
\text { logistics } \\
\text { networks }\end{array}$ & Carpets & Fibres \\
\hline
\end{tabular}

\section{CONCLUSIONS}

This paper presents a review of literature in reverse logistics. Several extensions are possible in reverse logistics. We could also study the case with competition between manufacturing and remanufacturing processes, namely, the manufacturing and remanufacturing taken by different firms. User friendly and smart decision support system may also be developed. Probabilistic demand pattern may also be considered in future studies.

\section{REFERENCES}

[1] K.Govindan, P.Murugesan,Q. Zhu, and K.Devika, "Analysis of third party reverse logistics provider using Interpretive Structural Modelling,', International Journal of Production Economics,vol.140,No.1,pp.204-211,2012.

[2] O.Lavastre, A.Gunasekaran, and A.Spalanzani, "Supply chain risk management in French companies", Decision Support Systems, vol.52, No.4, pp. 828-838, 2012.

[3] I. Ferna'ndez, T. Kek"ale, " Better models with Delphi and analytic hierarchy process approaches: the case of reverse logistics", International Journal of Logistics Systems and Management, vol.4, No.3,pp. 282-296,2008.

[4] V.Ravi, Ravi Shankar and M.K.Tiwari," Selection of a reverse logistics project for end-of-life computers: ANP and goal programing approach', International Journal of Production Research, Vol.46, No.17, pp. 4849-4870, 2008.

[5] K.M.Sheriff, A.Gunasekaran, \& S.Nachiappan, “ Reverse logistics network design: a review on strategic perspective', International Journal of Logistics Systems and Management, vol.12, No. 2, pp. 171-194, 2012.

[6] S.Dowlatshahi, " A framework for the role of warehousing in Reverse Logistics", International
Journal of Production Research, vol.50, No.5, pp. 1265-1277, 2012.

[7] S.K.Srivatsava , R.K.Srivatsava, “ Managing product returns for reverse logistics', International Journal of Physical Distribution and Logistics Management,vol.36,No.7, pp.524-546,2006.

[8] S.Rubio, A.Chamorro., \& F.J.Miranda, "Characteristics of the research on reverse logistics (1995-2005)',. International Journal of Production Research, vol.46, No.4, pp.1099-1120, 2008.

[9] S. Pokharel, \& A.Mutha, " Perspectives in reverse logistics: A review", Resources, Conservation and Recycling, vol.53, No.4, pp. 175-182, 2009

[10] Bernon M, Rossi S, Cullen J. Retail reverse logistics: a call and grounding framework for research. International Journal of Physical Distribution \& Logistics Management Vol. 41, No.5, pp. 484-510, 2011.

[11] Li X, Olorunniwo F. "An exploration of reverse logistics practices in three companies", Supply Chain Management: An International Journal, Vol.13, No.5, pp.381-386, 2008.

[12] Tseng ML. "Green supply chain management with linguistic preferences", Applied Soft Computing, Vol.11, No. 8, pp.4894-4903, 2011.

[13] Ko M, Tiwari A, Mehnen J . "A review of soft computing applications in supply chain management', Applied Soft Computing, Vol.10, No.3, pp.661-674, 2010.

[14] Tan AWK, Kumar A. " A decision making model for reverse logistics in the computer industry", International Journal of Logistics Management, Vol.17, No.3, pp.331-354, 2006.

[15] Savaskan RC, Bhattacharya S, Wassenhove LNV, "Close loop supply chain models with product remanufacturing', Management science, Vol.50,No.2,pp. 239-252, 2004.

[16] J.Wei, and J.Zhao. Pricing decisions with retail competition in fuzzy closed-loop supply chain, Expert Systems with Applications, Vol.38, No. 9, pp. 11209-11216, 2011.

[17] A.H.I.Lee, H.Y. Kang, C.F.Hsu , H.C.Hung, “A green supplier selection model for the high tech industry', Expert Systems with Applications, vol.36, No.4, pp.7917-7927, 2009.

[18] H.T.Liu, and W.K.Wang, “An integrated fuzzy approach for provider evaluation and selection in third party logistics", Expert Systems with Applications, vol.36, No. 3,pp. 4387-4398,2009.

[19] L.Q.Dat, D.T.T.Linh, S.Y.Chou, V.F.Yu, "Optimizing reverse logistics cost for recycling endof-life electrical and electronic products", Expert Systems with Applications, vol.39,No.7,pp. 63806387,2012 .

[20] K.K.Pochampally,S. Nukala, and S.M.Gupta, "Ecoprocurement strategies for environmentally conscious manufacturers', International Journal of Logistics Systems and Management, vol.5, No.1-2, pp.106122, 2009. 
[21] G.Buyukozkan \& .G.Cifci, “A novel hybrid MCDM approach based on fuzzy DEMATEL, fuzzy ANP and fuzzy TOPSIS to evaluate green suppliers', Expert Systems with Applications, vol. 39,No. 3,pp.3000-3011,2012.

[22] M. Biehl, E.Prater, and M.J. Realff, "Assessing performance and uncertainty in developing carpet reverse logistics systems", Computers \&. Operations Research, vol.34, No.2, pp. 443-463, 2007.

[23] K.K.Pochampally, and S.M.Gupta, "A multiphase fuzzy logic approach to strategic planning of a reverse supply chain network', IEEE Transactions on Electronic Packaging Manufacturing, vol.31, No.1, pp. 72-82, 2008.

[24] S. Rahman, and N.Subramanian, "Factors for implementing end-of-life computer recycling operations in reverse supply chains". International Journal of Production Economics, vol.140, No.1, pp. 239-248, 2012.

[25] S.Vachon, and R.D.Klassen, "Environmental management and manufacturing performance: the role of collaboration in the supply chain', International Journal of Production Economics, vol. 111, No. 2, pp. 299-315, 2008.

[26] Ramírez. A, "Product return and logistics knowledge: Influence on performance of the firm'. Transportation Research Part E: Logistics and Transportation Review, vol.48, No.6, pp. 1137-1151, 2012

[27] Byrne.P.M."Supply chain outsourcing: more choices, tougher decisions', Logistics Management, vol.45, No. 5, pp.24-26, 2006.

[28] G.Kannan, \& P.Murugesan. "Selection of third party reverse logistics provider using fuzzy extent analysis", Benchmarking: An International Journal, vol.18, No.1, pp.149-167,2011.

[29] M.Azadi, and R.F.Saen, "A new chance-constrained data envelopment analysis for selecting third-party reverse logistics providers in the existence of dualrole factors', Expert Systems with applications, vol.38,No.10,pp.12231-12236,2011.

[30] Y.Zhi-Hong, \& L.Qiang, "The grey comprehensive evaluation models of a third party reverse logistics provider selection', Proceedings of the International Joint Conference on Artificial Intelligence, 2009.

[31] L.M.Meade, and J.Sarkis, "A conceptual model for selecting and evaluating third party reverse logistics provider', Supply Chain Management: An International Journal, vol.7, No. 5, pp. 283-295,2002.

[32] T.Efendigil, S. Onut, and E.Kongar, "A holistic approach for selecting a third party reverse logistics provider in the presence of vagueness", Computers and Industrial Engineering, vol.54,No.2,pp.269287,2008 .

[33] S.H.Amin, and G.Zhang, "An integrated model for closed-loop supply chain configuration and supplier selection: Multi-objective approach', Expert Systems with Applications, vol.39, No.8, pp. 67826791, 2012.
[34] M. Xiangru, "Study of evaluation and selection in third party reverse logistics provider', Proceedings of the International seminar on Business and Information Management,2008.

[35] G.Kannan, S.Pokharel, and P.SasiKumar, "A hybrid approach using ISM and fuzzy TOPSIS for the selection of reverse logistics provider', Resources Conservation and Recycling, vol. 54, No 1. pp. 2836, 2009.

[36] P.Sasikumar, and A.N. Haq, "Integration of closed loop distribution supply chain network and 3PRLP selection for the case of battery recycling", International Journal of Production Research, vol.49, No.11, pp.3363-3385, 2011.

[37] R.F.Saen," A new model for selecting third-party reverse logistics providers in the presence of multiple dual-role factors", International Journal of Advanced Manufacturing Technology, Vol.46, No.1-4.pp.405410, 2010.

[38] D.Francas, and S.Minner, "Manufacturing network configuration in supply chains with product recovery', Omega, vol.37, No.4, pp. 757-769, 2009.

[39] D.H.Lee, and M.Dong, "Dynamic network design for reverse logistics operations under uncertainty". Transportation Research Part E: Logistics and Transportation Review, vol.45, No. 1, pp. 61-71, 2009.

[40] M.S.Pishvaee, S.A.Torabi,and J.Razmi, “Credibility based fuzzy mathematical programming model for green logistics design under uncertainty' . Computers and Industrial Engineering, vol.62, No.2, pp. 624-63, 2012.

[41] J.E.Lee, M.Gen, and K.G.Rhee, "Network model and optimization of reverse logistics by hybrid genetic algorithm', Computers and Industrial Engineering, vol.56, No.3, pp. 951-964,2009.

[42] A.Mutha, and S.Pokharel, "Strategic network design for reverse logistics and remanufacturing using new and old product modules', Computers and Industrial Engineering,vol.56, No.1, pp. 334-346, 2009.

[43] H.Min,H.J. Ko, "The dynamic design of reverse logistics network from the perspective of third party logistics service providers", International Journal of Production Economics, vol.113,No.1,pp.176-192, 2008.

[44] S.K.Srivatsava , R.K.Srivatsava, “ Managing product returns for reverse logistics", International Journal of Physical Distribution and Logistics Management,vol.36,No.7, pp.524-546,2006.

[45] G.Kannan , A.N.Haq , M.Devika , “ Analysis of closed loop supply chain using genetic algorithm and particle swarm optimization', International Journal of Production Research,vol.47, No.5, pp.1175-1200, 2008.

[46] J.N.Figueiredo, and S.F.Mayerle, "Designing minimum-cost recycling collection networks with required throughput', Transportation Research Part E: Logistics and Transportation Review, vol.44, No.5, pp. 731-752, 2008. 
[47] Vahdani, R.Moghaddam, M. Modarres and A.Baboli, "Reliable design of a forward/reverse logistics network under uncertainty: A robust-M/M/c queuing model', Transportation Research Part E: Logistics and Transportation Review, Vol. 48, No.6, pp. 11521168, 2012.

[48] L.Kroon, and G.Vrijens, " Returnable containers: an example of Reverse Logistics", International Journal of Physical Distribution and Logistics Management, vol.25, No. 2, pp. 56-68, 1995.

[49] R.Piplani, and A. Saraswat, "Robust optimisation approach to the design of service networks for reverse logistics', International Journal of Production Research, vol.50, No.5, pp. 1424-1437, 2012.

[50] N.Mishra, V.Kumar,and F.T.S Chan, “A multi-agent architecture for reverse logistics in a green supply chain', International Journal of Production Research, vol.50, No.9, pp. 2396-2406, 2012.

[51] G.Kannan,A.N. Haq ,M. Devika, “Analysis of closed loop supply chain using genetic algorithm and particle swarm optimization", International Journal of Production Research ,vol.47,pp. 1175-1200,2008.

[52] G.Tuzkaya, B.Gülsün, and Ş. Önsel, “A methodology for the strategic design of reverse logistics networks and its application in the Turkish white goods industry'. International Journal of Production Research, vol.49,No.15, pp.4543-4571.2011.

[53] K.Lieckens, and N.Vandaele, "Multi-level reverse logistics network design under uncertainty", International Journal of Production Research, vol.50, No.1, 23-40, 2012.

[54] M. Ramezani, M.Bashiri, and R.TavakkoliMoghaddam, "A new multi-objective stochastic model for a forward/reverse logistic network design with responsiveness and quality level', Applied Mathematical Modelling, vol.37, No.1, pp. 328$344,2013$.

[55] P.Guiltinan, N.Nwokoye, "Developing distribution channels and systems in the emerging recycling industries". International Journal of Physical Distribution, vol.6,No.1,pp. 28-38,1975.

[56] G.Bronstad, K.Evans-Correia, "Green purchasing: the purchasing agent's role in corporate recycling'. Conference proceedings of the national association of purchasing management, pp. 117-121,1992.

[57] R. Kopicki, M. Berg, L.Legg, V.Dasappa, and C.Maggioni, "Reuse and Recycling - Reverse Logistics Opportunities', Council of Logistics Management. Oak Brook, Illinois, 1993

[58] T.Gupta, and S. Chakraborty, "Looping in a multistage production system', International Journal of Production Research,vol. 22, pp.299-311,1994.

[59] M.Jahre, "Household waste collection as a reverse channel: a theoretical perspective', International Journal of Physical Distribution and Logistics Management, vol.25,No.2, pp.39-55,1995.

[60] A. Faria de Almeida, and A. Robertson "Domestic batteries and the environment: a life-cycleapproach to consumer electronic products', Proceedings
International Conference CleanElectronics Products and Technology, Edinburgh, Scotland, pp.162167,1995 .

[61] T.Spengler, H.Puchert, T. Penkuhn, O. Rentz, "Environmental integrated introduction and recycling management', European Journal of Operational Research,vol. 97,No.2, pp.308-326,1997.

[62] G.Yender, "Battery recycling technology and collection processes", Proceedings IEEE International Symposium on Electronics and the Environment, May, 30-35,1998.

[63] A.Barros, R. Dekker, V.Scholten, "A two-level network for recycling sand: a case study",European Journal of Operational Research, vol.110,No.2, pp.199-215,1998.

[64] C.Nagel, and P.Meyer, "Caught between ecology and economic: end-of-life aspects of environmental conscious manufacturing', Computers and Industrial Engineering, vol.36,No.4, pp.781-792.

[65] D.Louwers, B.Kip, E.Peters, F.Souren, and S. Flapper (1999), “A facility location allocation model forreusing carpet materials". Computers and Industrial Engineering, vol.36,pp. 855-869,1999.

[66] M.Realff, J.Ammons, D. Newton, "'Strategic design of reverse production systems". Computers and Chemical Engineering, vol.24, 991-996,2000.

\section{BIOGRAPHIES}

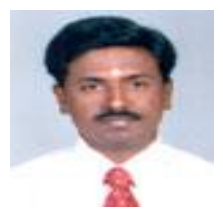

Mr.S.Senthil is currently working as Associate Professor in Kamaraj College of Engineering and Technology, Virudhunagar.

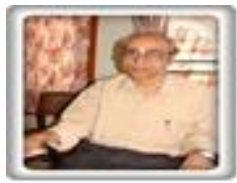

R.Prof. R. Sridharan is working as Professor in the Department of Mechanical Engineering at National Institute of Technology, Calicut. 